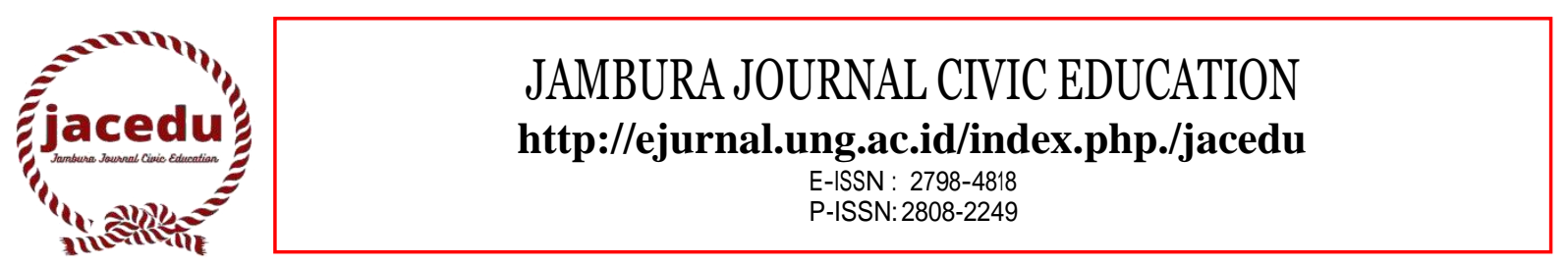

\title{
NILAI-NILAI DEMOKRASI SEBAGAI LANDASAN BERPIKIR KRITIS MAHASISWA.
}

\author{
Rina Marlina 1 \\ STKIP Pasundan Cimahi \\ rinamarlina@gmail.com
}

\begin{tabular}{|c|c|}
\hline Info Artikel & Abstrak \\
\hline $\begin{array}{l}\text { Sejarah Artikel: } \\
\text { Diterima (Desember) (2021) } \\
\text { Disetujui (Desember) (2021) } \\
\text { Dipublikasikan (Desember ) } \\
\text { (2021) }\end{array}$ & $\begin{array}{l}\text { Perkembangan dan peningkatan pemahaman akan urgensi } \\
\text { demokrasi, telah membawa demokrasi sebagai salah satu isu yang tak } \\
\text { henti diperbincangkan. Hal tersebut merupakan implikasi dari } \\
\text { pandangan bahwa demokrasi dianggap sebagai model pemerintahan } \\
\text { yang paling baik dan dapat membawa negara menuju kesetaraan dan }\end{array}$ \\
\hline $\begin{array}{l}\text { Keywords: } \\
\text { Nilai demokrasi, } \\
\text { berpikir kritis. } \\
\end{array}$ & $\begin{array}{l}\text { kesejahteraan. Tujuan penelitian ini mengkaji dan menganalisis } \\
\text { aktivitas organisasi kemahasiswaan dalam memperkuat nilai-nilai } \\
\text { demokrasi sebagai landasan berpikir kritis mahasiswa. Metode yang } \\
\text { akan digunakan dalam penelitian ini yaitu metode grounded theory } \\
\text { karena penilitian diharapkan dapat menemukan konsep, pendekatan } \\
\text { atau teori baru yang berangkat dari temuan selama penelitian } \\
\text { dilakukan. Berdasarkan hasil observasi, studi dokumentasi, dan } \\
\text { wawancara yang dilakukan terhadap beberapa narasumber, peneliti } \\
\text { menemukan informasi kaitannya dengan aktivitas organisasi } \\
\text { kemahasiswaan dalam memperkuat nilai-nilai demokrasi. Sebelum } \\
\text { dibahas mengenai aktivitas-aktivitas yang dilakukan dalam } \\
\text { meningkatkan kemampuan berpikir kritis mahasiswa, perlu } \\
\text { ditemukenali terlebih dahulu kompetensi apa saja yang harus dimiliki } \\
\text { mahasiswa }\end{array}$ \\
\hline
\end{tabular}

\section{PENDAHULUAN}

Euphoria demokrasi di Indonesia telah menjalar pada segala aspek kehidupan sejak terjadinya Gerakan 1998, akan tetapi sampai saat ini harapan sebagaimana diinginkan masih jauh dari yang diindahkan, bahkan cenderung menunjukkan ketidakjelasan arah. Spirit penciptaan kehidupan demokratis telah merasuk pada seluruh eleman bangsa, tidak terkecuali dalam kehidupan mahasiswa di kampus. Mahasiswa di berbagai kampus di Indonesia senantiasa berserikat dan berkumpul membentuk suatu

\footnotetext{
${ }^{1}$ Dosen STKIP Pasundan Cimahi
} 
organisasi dan disebut sebagai "student government" sebagai adopsi dari pemerintahan negara. Permasalahan muncul ketika menguaknya konsep "student goverment" di kalangan mahasiswa yang justru tidak dimaknai secara khafah, dalam arti bahwa konsepsi pemerintahan mahasiswa (student government) yang seharusnya dipahami sebagai upaya menciptakan kampus sebagai wahana penggemlengan mental dan kemampuan kepemimpinan masa depan justru malah dijadikan arena pertarungan pencapaian "kekuasaan". Hal ini jelas mengindikasikan terjadinya pergeseran orientasi dan konsepsi kampus sebagai tempat menimba ilmu (termasuk kepemimpinan) bagi mahasiswa.

Perkembangan dan peningkatan pemahaman akan urgensi demokrasi, telah membawa demokrasi sebagai salah satu isu yang tak henti diperbincangkan. Hal tersebut merupakan implikasi dari pandangan bahwa demokrasi dianggap sebagai model pemerintahan yang paling baik dan dapat membawa negara menuju kesetaraan dan kesejahteraan. Banyak negara menganggap bahwa demokrasi merupakan sistem yang paling baik untuk digunakan oleh negara dalam konteks kekinian, karena mendasarkan segala aspek berdasarkan suara rakyat (bottom-up). Selain itu, berdasarkan telaah dan analisis yang dilakukan penulis menemukan sejumlah nilai yang kiranya terkandung dalam konsep demokrasi seperti; nilai kemandirian, nilai toleransi terhadap perbedaan pendapat, mengembangkan kemampuan untuk memahami budaya berselisih secara sehat dan demokratis dimana masyarakat diajarkan untuk mampu menjadi pembicara sekaligus pendengar yang baik.

Pembudayaan nilai-nilai demokratis merupakan salah satu dimensi dalam pembangunan karakter bangsa yang berdasarkan hasil penelitian Kardiman (2008) dalam studinya mengenai membangun kembali karakter bangsa melalui situs-situs kewarganegaraan menghasilkan temuan bahwa pembangunan karakter bangsa tidak saja menjadi tanggung jawab dunia persekolahan tetapi juga menjadi tanggung jawab situs-situs kewarganegaraan di luar persekolahan. Hal ini menegaskan bahwa pendidikan kewarganegaraan yang di mana di dalamnya terdapat pendidikan karakter (termasuk karakter demokratis), tidak hanya menjadi mata pelajaran persekolahan, tetapi menjadi pendidikan kewarganegaraan di lingkungan masyarakat (community civic education). 


\section{METODELOGI PENELITIAN}

Metode yang akan digunakan dalam penelitian ini yaitu metode grounded theory karena penilitian diharapkan dapat menemukan konsep, pendekatan atau teori baru yang berangkat dari temuan selama penelitian dilakukan. Sebagaimana dijelaskan Strauss \& Corbin (2003, hlm.12) bahwa grounded theory merupakan metode dalam penelitian kualitatif yang menggunakan sejumlah prosedur sistematis guna mengembangkan teori dasar, yang disusun secara induktif, tentang suatu fenomena. Temuan penelitiannya merupakan rumusan teori tentang realitas yang diteliti, bukan sekedar sederet angka atau sejumlah tema yang kurang berkaitan.

\section{HASIL PENELITIAN DAN PEMBAHASAN}

Organisasi kemahasiswaan sebagaimana diketahui, diyakini mempunyai posisi sebagai wahana pembelajaran berdemokrasi bagi mahasiswa. Optimalisasi organisasi kamahasiswaan sebagai laboratorium demokrasi dioperasionalisasikan dalam bentuk program kerja dan aktivitas organisasi yang mendorong terciptanya sikap saling menghargai, keberanian mengemukakan pendapat, budaya berselisih secara sehat, kemandirian, kepemimpinan, tanggungjawab pribadi dan sosial, dan lain sebagainya.

Berdasarkan hasil observasi, studi dokumentasi, dan wawancara yang dilakukan terhadap beberapa narasumber, peneliti menemukan informasi kaitannya dengan aktivitas organisasi kemahasiswaan dalam memperkuat nilai-nilai demokrasi. Sebelum dibahas mengenai aktivitas-aktivitas yang dilakukan dalam meningkatkan kemampuan berpikir kritis mahasiswa, perlu ditemukenali terlebih dahulu kompetensi apa saja yang harus dimiliki mahasiswa.

Dijelaskan Syahid, bahwa setidaknya terdapat tiga kompetensi yang harus dimiliki mahasiswa yang secara langsung ataupun tidak langsung berpengaruh terhadap kemampuan berpikir kritis mahasiswa. Beberapa kompetensi yang harus dimiliki mahasiswa tersebut senada dengan visi dan misi pendidikan tinggi, meliputi; kompetensi personal (kepribadian), kompetensi akademik (berpikir ilmiah), dan kompetensi profesional (kemampuan bidang studi masing-masing).

Kaitan dengan itu, Syahid menjelaskan bahwa pembinaan kemahasiswaan haruslan mendorong terciptanya mahasiswa yang berkepribadian utuh, mampu berpikir ilmiah (kritis) dan profesional dalam bidangnya masing-masing sesuai dengan keilmuan yang digelutinya. 
Pertama, pengembangan kompetensi personal dilakukan melalui general education (Mata Kuliah Dasar Umum) yang wajib diikuti oleh seluruh mahasiswa di semua Departemen atau program studi yang ada di Universitas Pendidikan Indonesia. Syahid menjelaskan kompetensi dalam kaitannya dengan pengembangan akhlak mulia dilakukan melalui mata kuliah Pendidikan Agama, penguatan kompetensi warganegara dilaksanakan melalui mata pelajaran pendidikan kewarganegaraan, dan penguatan jatidiri bangsa dilakukan melalui pengajaran bahasa indonesia. Selain itu, dijelaskan Syahid bahwa pengembangan kompetensi personal, selain melalui kegiatan kurikuler juga dilaksanakan melalui kegiatan ekstrakurikuler melalui organisasi kemahasiswaan. Kepribadian yang dikembangkan melalui organisasi kemahasiswaan ini misalnya; tanggung jawab, kemandirian, kepemimpinan, dan lain sebagainya.

Kedua, pengembangan kompetensi akademik dijelaskan Syahid selain dilaksanakan melalui kegiatan pertkuliahan juga dapat dilakukan melalui pembinaan kemahasiswaan. Pihaknya menjelaskan bahwa sebagai orang yang membidangi kegiatan pembinaan kemahasiswaan, organisasi kemahasiswaan yang ada di Universitas Pendidikan Indonesia mempunyai posisi strategis dalam mendukung terbangunnya kemampuan akademik mahasiswa, terutama dalam kaitannya dengan penalaran dan pengembangan cara berpikir mahasiswa dalam menyikapi berbagai persoalan yang dihadapi bangsa. Dikatakan seperti demikian, karena menurut Syahid kemampuan akademik bukan hanya dimaknai sebagai kemampuan mahasiswa dalam kegiatan akademik, dalam arti penyelesaian tugas-tugas mata kuliah di kelas. Akan tetapi, hendaknya dipahami sebagai pengembangan kemampuan berpikir ilmiah, yakni berbagai kemampuan berpikir secara sistematis,kritis, linier, logis dan komprehensif.

Ketiga, dalam hal pengembangan kompetensi profesional selama ini dilakukan oleh departemen/program studi melalui Praktik Pembelajaran Lapangan (PPL) dan atau Kuliah Kerja Lapangan (KKL) sesuai dengan bidang studi yang diikuti oleh masingmasing mahasiswa. Sekaitan dengan itu, direktorat pembinaan kemahasiswaan yang secara terstruktur dan operasional masuk dalam program universitas secara khusus mengurusi organisasi kemahasiswaan sebagai program ekstrakurikuler yang keberadaannya tidak ddapat lepas dari universitas dan pengembangan kompetensi mahasiswa. 


\section{KESIMPULAN}

Aktivitas yang berkait dengan penguatan kemampuan berpikir kritis mahasiswa, tidak hanya dilakukan dengan kajian, audiensi dan aksi saja. Akan tetapi, organisasi kemahasiswaan mempunyai cara tersendiri dan lebih kreatif dalam membangkitkan kesadaran berpikir kritis mahasiswa.

\section{DAFTAR PUSTAKA}

Bahmuller, C. E. (1996) The Future of Democracy and Education for Democracy, Calabasas: Center for Civic Education (CCE)

Branson, M.S. 1998. The Role of Civic Education. Calabasas: CCE. (1999) Making the Case for Civic Education: Where We Stand at the End of the $20^{\text {th }}$ Centure, Washington : CCE

Creswell, J.W. (2008). Educational Research (Planning, Conducting and Evaluating Quantitative and Qualitatif Research (Third Edition). California: University of Nebrasca-Lincoln.

Effendy, OU. (2007). Komunikasi Organisasi. Bandung : PT Remaja Rosdakarya.

Kardiman, Y. (2008). Membangun Kembali Karakter Bangsa Melalui Situs-Situs Kewarganegaraan (Studi Fenomenologi terhadap Pelatihan Manajemen Qalbu, Pelatihan Emotional Spiritual Quotient dan Majelis Taklim di Bandung). Bandung: Tesis Pada Program Studi Pendidikan Kewarganegaraan SPs UPI Bandung.

Strauss, A \& Corbin, J. (2003). Dasar-Dasar Penelitian Kualitatif: Tatalangkah dan TeknikTeknik Teoritisasi Data. Terjemahan oleh: Muhammad Shodiq dan Imam Mutaqien dari Judul Basics of Qualitative Research: Grounded Theory Procedures and Techniquee. Yogyakarta: Pustaka Pelajar 